\title{
Marriage in Renaissance Drama: Defiance of Patriarchal Authority and Social Conventions
}

\author{
Ibrahim Abushihab \\ English Department, Alzaytoonah University of Jordan, Amman, Jordan \\ E-mail: facultyofarts2@yahoo.com \\ Esraa Abushihab \\ Yarmouk, University of Jordan, Irbid, Jordan
}

Received: 08-04-2016

Published: 01-09-2016
Accepted: 11-06-2016

doi:10.7575/aiac.ijalel.v.5n.5p.92
Advance Access Published: July 2016

URL: http://dx.doi.org/10.7575/aiac.ijalel.v.5n.5p.92

\begin{abstract}
This paper focuses on the miserable position of women and marriage issues in Renaissance drama. Women were generally considered as a threat to male authority. Girls did not have the right to choose their future husbands and were mostly obliged to marry men they did not like because their choice was based on the principles of the law and norms. Under these miserable conditions, some writers of the period strived to change the negative position of society and challenged the tyranny of male authority. In Elizabeth Cary's The Tragedy of Mariam (1613) and John Webster's The Duchess of Malfi (1612), Mariam and the Duchess reject the demands of their society to be obedient, and raise voices to assert their selfhood. Mariam decides to get rid of these restrictions by breaking the convention of the silent women and to challenge her husband's authority, and that of her patriarchal society. On a parallel line, The Duchess attempts to deny the authority of social conventions and impose her identity in a patriarchal society. They are rebellious women who refuse to be under male authority and represent the contradictions of female identity in patriarchal cultures. They could not bear their humiliation in their society, and they want to lead a normal life without being controlled. Both die at the end and pay their lives for defying patriarchal authority and social conventions.
\end{abstract}

Keywords: Feminism, Renaissance, Drama, Rebellious women

\section{Introduction}

Throughout the ages, women encountered many problems and difficulties in their lives. In Renaissance era, most of them were deprived of their rights. They were controlled by their parents in their childhood, and then handed over to their husbands who controlled everything in their lives as well. Unmarried girls had to spend their lives as nuns in convents under male authority. They were born to be subjected to male authority and were expected to be dutiful to their fathers and husbands and restricted themselves to feminine activities such as child-rearing. Mothers at home widened the gap between males and females by the way they raised their children. They believed that masculinity, unlike femininity, associated to strength, responsibility and success. Marriages were arranged, not by the two people getting married, but by their parents and other relatives. Marriage might provide a way of combining adjacent estates or of concluding a peace treaty. A married couple was regarded by the law as a single entity and that entity followed the will of the husband.

\section{Discussion}

During the period 1550-1603, England had five uninterrupted decades of powerful female rulers like Lady Jane Grey, Mary I, and Elizabeth I, but they did not show or have any effective impact on the role of women. Queen Elizabeth I was considered as a successful woman and given credit for England's remarkable prosperity, stability, and cultural achievement during her reign, but she did not change the negative role of women in society, neither did she promote other women to positions of authority or encourage the extension of greater rights to women. In the Faerie Queene, Edmund Spenser ironically asserted that women were treated as slaves, and no one cared for them. In English Renaissance Drama, male authority was mostly highlighted, but the voice of women was suppressed because they were generally considered a threat to male authority. Some examples of suppressed female characters in Renaissance Drama are in Ophelia and Gertrude in Shakespeare's Hamlet, Anne in Thomas Heywood's A Woman Killed with Kindness, and Annabella in John Ford 'Tis Pity She's a Whore. Such examples highlight the stereotype dominance of men over women. Women were submissive and were obliged to accept their miserable conditions. Burks (1995) points out those girls had no autonomy to choose their husbands. This was because the English law at that time did not allow any legal marriage without the approval of the girl's father who mostly obliged her to marry a man whom he chose for her. Many Renaissance plays dealt with the marriage issue and the dangers of breaking the accepted norms and according to Pohlig (2009), adultery was unsatisfactory relationship because it was against the social customs and it was a more complicated than legitimate marriage. 
Under these miserable conditions, some women writers of the period tried to change the negative position of society towards women. Elizabeth Cary (1585-1639) together with other enlightened dramatists started to reject the demands of society, and raised voices to assert their selfhood. Though Cary's name may be unfamiliar to all but scholars in the admittedly niche field of early modern women's writing, she is without question a critical figure in the history of English literature and drama. Her play The Tragedy of Mariam was the most important play written by a woman of the time. In this play which was published in 1613, Mariam put the blame on her patriarchal society and struggled against male-authority of her parents and her husband.

Cary focuses on the development on Mariam's character. As Beilin (1998) mentions "Cary's Mariam is psychologically more complex" (p.169). Herod wishes that he would come back and find Mariam still under his control. Mariam expresses her sadness and refusal to be under Herod's control by wearing a dusky dress. She insists that she does not want to live under his control any more. When she is asked about her dress, she tries to deceive him by saying it is to mourn her father and brother. She does not tell him that she wears it to express her sorrow about her independence. At the same time, the dusky dress represents the beginning of her revolution against her husband's authority and against male restrictions and oppression.

The play ends sadly. Mariam is not able to live under her husband's control and insists to revolt against slavery; therefore, she is executed. In her article "The Specter of Resistance: The Tragedy Of Mariam", Ferguson (1991) says "After the execution, which is described by a messenger, Herod spends most of the final act regretting, as Othello does, the loss of his 'jewel.' Unlike Othello, however, this jealous husband, created by a female playwright, laments not only his innocent wife's death but, specifically, the loss of her too valued powers of speech" (183).

At the beginning of the play, Cary decides to free her soul by creating the fictional character of Mariam. Some critics like Davies (1986) say that "Woman in life and woman in art are not the same person" (p. 1). Elizabeth Cary tries to gather between both of them. When she presents Mariam, she talks about herself. This character would do what Cary wants to do in reality, but she knows that she could not do that because of her patriarchal society "when virgin freedom left me unrestrained" (I. 74). Cary lives in a patriarchal society which prevents her from doing what she wants to do. As a result, she wants to live her life freely, writing and describing her fantasies.

Feminist critics have shown tremendous interest in Mariam who tries to revolt against the negative role of women. She wants to assert the female identity in a patriarchal society. Cary's play poses the problem of a public voice, and the danger of female public speech. At the beginning of the play, Mariam is confused between her feminine duty and her conscience. One can feel her problems during her long soliloquy. Some critics tend to believe that Cary talks about her life when she presents Mariam. She could in one sense "have applied Mariam's opening question to herself and answered it with decorum fictional character lacks" (Ferguson 185). One feels that her public voice would annoy her patriarchal society.

$$
\begin{gathered}
\text { How oft have I with public voice run on } \\
\text { To censure Rome's last hero for deceit: } \\
\text { Because he wept when Pompey's life was gone, } \\
\text { Yet when he lived, he thought this name too great... } \\
\text { My sex pleads pardon, pardon then afford, } \\
\text { Mistaking is with us but too common. } \\
\text { Now do I find, by self-experience taught (I. 1-9). }
\end{gathered}
$$

Mariam is shown as a woman restricted by a patriarchal tradition, but she decides to get rid of these restrictions by breaking the convention of the silent women. Cary starts her play by describing the miserable lives of women who were treated as inferior. She highlights the problem of women as wounds which bleed all the time. As a Renaissance writer, she wants to heal these wounds by declaring her rejection of this miserable situation which she does not accept anymore.

Cary expands the authority of the female protagonist by giving her the position of widowhood which is the most powerful position available in Renaissance period. The supposed death of her husband makes her discover her complex feelings which lead her to discover her selfhood and her rights.

Mariam is different from women in Renaissance drama. She refuses to be under the restraints of patriarchal society. Cary shows two types of women, the first is that under male control, and the second is those who decide to revolt against patriarchal society. She breaks the convention of the silent women and decides to challenge her husband's authority, and that of her patriarchal society. In his article "Women's Position in the Renaissance Period: The Case of The Tragedy of Mariam", Wang (2010) believes that Mariam challenges her husband's authority and maintains her physical and moral virtues. Mariam is at the crossroads of her life. She has two choices, the first one is to return to her husband's authority, and the other one is to gain her selfhood and her public voice:

Mariam: I know I could enchain him with a smile:

And lead him captive with a gentle word,

I scorn my look should ever man beguile

Or other speech than meaning to afford (III. 163-166). 
In their study of Mariam, some critics make a comparison between her and Desdemona in Shakespeare's play Othello. Both Mariam and Desdemona are killed by their husbands, and both do not make any kind of resistance against their death. In "Sex and the Female Tragic Hero" Roberts (2002) thinks that "Desdemona is a threat to the community's values, but her sacrifice as victim does nothing to cleanse or alter her society... Desdemona does have a distinctive voice, but her one independent action precedes the action and she personifies a male stereotype in which sex leads to death. She is certainly sympathetic, but hardly heroic" (203). yet we distinguish a big difference between Mariam and Desdemona. While Mariam refuses to give up her ideas against patriarchal society, Desdemona does not try to defend her situation. Some critics say that Shakespeare shows Desdemona at the beginning as a rebellious girl, who revolts against her father's will and against the conventions of society, and marries Othello, but her voice is suppressed. Other critics say that Cary wants to hallow Mariam by showing a similarity between her and Christ. This comparison comes from the relation between Christ and the phoenix. In "Elizabeth Cary" (1585-1639), Beilin (1998) mentions that "The resurrection of the phoenix traditionally symbolizes the resurrection of Christ and the death of Mariam mirrored that event. She is calm and mild; her look keeps "the world in awe"' (176). At the end of the play, Cary presents Mariam as a Christ figure because the person who sacrifices himself for others is like Christ. By mentioning the Phoenix, Cary tries to give Mariam a heroine's death, because the Phoenix is a symbolic bird that produces small birds after its death. The death of the Phoenix gives life, and the death of Mariam also gives life for other women.

John Webster's The Duchess of Malfi (published in 1612) continues to resonate among modern audiences because of the Duchess's enterprising attempt at denying the authority of social conventions and norms over her will to choose a spouse for love. Webster highlights the fact that no woman is above the patriarchal authority. Although the Duchess has a political position, she is controlled by her brothers. Accordingly, Ferdinand and the Cardinal terrorize her with fearful and cruel speech, because they do not want her to slip out of the patriarchal grip:

Ferdinand: Such weddings may more properly be said

To be executed than celebrated.

Cardinal: The marriage night

Is the entrance into some prison.

Ferdinand: And those joys,

Those lustful pleasures are like heavy sleeps

Which do fore-run man's mischief...

Duchess: I think this speech between you both studied,

It came so roundly off (I. 320-329).

At Renaissance time, women could not face their society because if they tried, they would be punished severely. Jankowski (2001) discusses the female sovereign, and the sovereign's marriage "the widow attempts to secure herself politically by divorcing her natural body from her political one by creating a private second marriage that exists simultaneously with-but hidden from her public life as a ruler" (222). She challenges Renaissance society's views regarding the presentation of the female body and sexuality.

The Duchess's marriage to Antonio is at the focal point of the play, as it contradicts the established practices and wishes of the patriarchal aristocracy. She makes her way through the feudalistic aspects of aristocratic society by following her own desires privately, while publicly pretending to obediently follow her brothers' wishes, as in the play's first scene when she claims to her brothers that she will not marry. The Aragonian brothers are both figures of society's authority: the Cardinal is a high ranking official in the Roman Catholic Church and Ferdinand is a Duke and an established member of the aristocracy. The Duchess's marriage challenges both aspects of society represented by her brothers. Marrying Antonio represents her attempt to authorize her divergence from her brothers' orders and the traditional ideology that they employ.

The position of Webster's Duchess suggests her responsibility to her family in terms of her marital status. Her coded response to Ferdinand's false claim that he plans to arrange for the Count Malateste to become her spouse is revealing: "A count? He's a mere stick of sugar candy; / You may look quite through him. When I choose / A husband, I will marry for your honor" (3.1.42-44). In fact, the Duchess falsely implies her subordination to the patriarchal nature of arranged marriages in an attempt to prevent Ferdinand from discovering her unsanctioned marriage.

The Duchess defies the tendencies of the time by choosing to remarry despite the fact that she is not financially obligated to do so. The socially unequal match between her and Antonio acts as a catalyst that destabilizes relationships and time-honored social practices and conventions. The play's depiction of the downward spiral into chaos is brought about by a strict society's inability to handle the Duchess's re-appropriation of conventions and shifting ideologies in order to create an environment that authorizes her astonishing choice of partners. However, the story of the Duchess and her steward, Antonio, ends tragically with their murders as punishment for violating social norms. Yet, in the face of losing everything, the Duchess "maintains her independence by refusing to submit to her brothers' will as she denies madness and wishes for her own death" ("Reaffirming the Male Ambition in John Webster's The Duchess of Malfi"). Her actions and motives are not driven by political ambition, but rather driven by a need to seek her own identity in a world where the patriarchal Ferdinand does not allow her a public or private identity. 


\section{Conclusion}

In Renaissance era, it is a must for women to obey their fathers and husbands. Unfortunately, women are lower than men and have to be controlled by men. Leinwand (1986) argues that women are lower in status in comparison with men. They are lower than men physically, mentally and morally. Women are wrongly considered the source of sin and evil because they are daughters of Eve who is the cause of dismissal of Adam from the Garden of Eden. Accordingly, culture and literature are based on this trend, so they are deprived from freedom, Leinwand (ibid) states that, in comparison to servants, they are treated better, but the society gives them less freedom than men. Women are imprisoned in the marriage relationship which restricts their freedom. Men control the social, political, religious, and economic lives of the whole society, especially those of women. Many Renaissance writers try to bind between marriage and religious issues. Plays written by Renaissance dramatists provide voices in which women characters speak of their struggle over marriage and the restrictions imposed on them. Marriage obliges women to be under control all the time.

Mariam and the Duchess are presented as rebellious women who refuse to be under male authority. Critics focus on them as characters representing the contradictions of female identity in patriarchal cultures. Both characters have the right to choose one of the following two paths: the first is to give vent to their grievances and challenge their societies regardless of the dangerous consequences. The second one is to abide by the supremacy of men, and the social code of their societies. They cannot bear their humiliation in their society, and they want to lead a normal life without being controlled. Accordingly, both have chosen the first rugged path and have decided to challenge the norms and customs of their societies. Bergon (1998) in "Women as patrons of English Renaissance Drama" says that several writers detect a miserable status of women after the Death of Elizabeth, but the positive role of women in society is dealt with because of the development of women's rights movements (p.69). Some feminist critics, like Mary Wollstonecraft, have called for equality between men and women, and have developed a movement currently called Feminism. This movement melts gender differences, and asks for women's rights. It helps women become aware of their oppression in the patriarchal society.

\section{References}

Beilin, E. V. (1998). Elizabeth Cary (1585-1639). Readings in Renaissance Women's Drama, 167-181.

Bergon, D. M. (1998). Women As Patrons of English Renaissance Drama. Readings in Renaissance Women's Drama, 69-80.

Burks, D. (1995). I'll Want My Will Else: The Changeling and Women's Complicity with their Rapists". English Literary History, 62(4), 759 - 790.

Cary, E. (1994). The Tragedy of Mariam, the Fair Queen of Jewry. University of California Press.

Davies, S. (1986). The Idea of Woman in Renaissance Literature: The Feminine Reclaimed. Brighton: Harvester.

Ferguson, M. W. (1991). The Spectre of Renaissance: The Tragedy of Mariam (1613). Readings in Renaissance Women's Drama, 182-193.

Jankowski, T. A. (2001). Defining/Confining the Duchess: Negotiating the Female Body in John Webster's The Duchess of Malfi. Studies in Philology, 221-245.

Leinwand, T. (1986). The City Staged Jacobean Comedy, 1603-1613, Madison: WI: University of Wisconsin Press.

Pohlig, V. (2009). Adultery in Early Stuart England, PhD, Der Freien Universitat Berlin.

----- (---). Reaffirming the Male Ambition in John Webster's The Duchess of Malfi. Essays and Articles on Webster. Anniina Jokinen .December 15, 1999. Web. 2 May. 2016.

Roberts, J. A. (2002). Sex and the Female Tragic Hero. In N. C. Liebler, The Female Tragic Hero in English Renaissance Drama (pp. 199-218). New York: Palgrave.

Wang, Ya-hue (2010). Women Position in the Renaissance period: the case of the Tragedy of Mariam. Theater, Dance and Performance Studies, 1-10. 